\section{Histórias do Mineirão}

\section{Ewerton Martins Ribeiro}

A revista FuLiA apresenta a inédita e "saborosíssima série de pequenas narrativas de episódios curiosos e surpreendentes da vida dos torcedores mineiros", escrita por

Ewerton Martins Ribeiro, escritor de ficção e jornalista da Universidade Federal de Minas Gerais. Publicou $A$ Grande Marcha (2014), seu primeiro romance, pelas editoras e-galáxia (ebook) e Circuito (impresso).

É mestre em Literatura Brasileira pela Faculdade de Letras da UFMG, com trabalho sobre Fernando Sabino intitulado Retrato de um escritor bifurcado e de sua paixão pela literatura. Atualmente, realiza pesquisa de doutorado em Teoria da Literatura e Literatura Comparada pela mesma universidade.
O pai de um amigo nunca tinha ido ao Mineirão. Vivera no interior a vida toda, vida de roça, e só se mudara para a capital na velhice, para cuidar da saúde. Mesmo com televisão em casa, sempre preferiu ouvir os jogos pelo rádio: achava o máximo ficar sabendo do gol segundos antes de todo mundo, ainda que nunca houvesse compreendido muito bem por que aquilo acontecia.

Certo dia, já com o pai instalado na cidade, o filho cismou de levar o homem para conhecer o estádio. Comprou ingressos para um jogo tranquilo, do campeonato regional, e seguiu rumo à Pampulha. Na entrada, emocionou-se com o assombro do velho ao mirar o estádio pela primeira vez.

— É bonito demais - dizia o pai, radinho colado ao ouvido -, bonito demais.

O jogo seguiu sem graça, empate sem gols, até que perto do fim o juiz apitou um pênalti para o time da dupla. Emocionado, o pai abraçava o filho, gritando o nome do clube.

De repente, o homem prostrou-se desanimado, sem querer olhar para o campo. Quando viu que o filho o encarava, acabou não se contendo; disse baixinho, o rádio sempre ao ouvido: 
- Quer esperar a imagem ou te falo de uma vez que ele bateu para fora?

Assim que ouviu o pai, o filho olhou pro campo e, tomado pelo absurdo, pôde finalmente acompanhar o atacante isolar a bola por cima do travessão.

\section{$* * *$}

Um caso que não esqueço é o daquela mocinha que, feliz por ter conseguido comprar um ingresso para as semifinais da Copa do Mundo, acabou vivenciando a imponderável sensação de ver a Alemanha meter sete gols na seleção brasileira em pleno Mineirão. Um amigo que presenciou a cena me contou das suas emoções durante o jogo.

Segundo meu chapa, a menina gemeu baixinho no primeiro gol, chorou tragicamente no segundo, revoltou-se no terceiro (a ponto de xingar as mães de cada um dos nossos onze jogadores no quarto), resignou-se ali pela altura do quinto, nem reparou quando a Alemanha fez o sexto e, na iminên- cia do sétimo gol, acabou foi caindo na gargalhada, incontrolável, constrangendo o choro dos que estavam ao redor.

0 marido, da sua parte, constrangia-se era com o show oferecido pela mulher - de forma que, na impossibilidade de fazê-la calar, saiu-se como pôde: fingiu que não conhecia. Ao que se diz, a moça só parou de rir quando o Brasil fez o gol de honra: por algum motivo, ela achou que aí perdeu a graça para o alívio do marido.

O caso a seguir aconteceu com um primo meu, e eu juro pela fraternidade de nossas mães que ele se deu como eu o conto aqui.

Meu primo foi ao estádio com três dos nossos amigos e, mesmo chegando cedo ao Mineirão, não escapou de ser interceptado por um flanelinha na hora de estacionar.

- Trinta reais para garantir a segurança do patrimônio, ô chefia.

- Trinta? Trinta?! Mas se o ingresso pro jogo custa a metade disso! 
— Sabe como é, né, chefia: é a macroeconomia - e meu primo jura que o sujeito falou mesmo em macroeconomia. Depois de uma negociação emburrada, pagaram quinze, ainda contrariados.

No estádio, minha turma comia o tropeiro que o diabo amassou: pelo desempenho pífio do nosso time, tudo indicava o revés. Foi quando, num contra-ataque de sorte, nosso goleiro lançou a bola nos pés do lateral, que pedia substituição à beira do gramado, na iminência do campo do adversário, marcando o cansaço.

Livre e desimpedido, o rapaz até ensaiou uma corrida em direção à linha de fundo, mas, na falta de pernas, acabou foi metendo a bica dali mesmo, no último fôlego. Os acasos do futebol: em vez de centrar para o atacante, que corria esbaforido pelo meio, o lateralzinho acabou acertando direto no gol, encobrindo o goleiro.

Emocionados, os torcedores se abraçavam a esmo, sem poder acreditar. Foi nessa hora que, cantando o hino com o braço jogado sobre os ombros de um qualquer, meu primo cismou estar abraçando algum conhecido de antigamente.
Afastou-se para então ver seu rosto - e emudeceu. Pois não era o flanelinha que havia levado os seus quinze reais para vigiar o carro?

A boca espumando, meu primo por pouco não lhe meteu a mão na cara. Contido pelos nossos amigos, terminou apenas exigindo o ressarcimento do dinheiro, talvez tocado pela preferência clubística do rapaz. Foi quando ouviu, sem poder acreditar:

- Xi, não vai dar jeito, chefia: precisei para comprar o ingresso.

Certa vez conheci dois casais que, amigos entre si, viveram uma situação inusitada no gigante da Pampulha. Um casal era formado por uma moça cruzeirense e um rapaz atleticano; no outro, a situação era inversa - e disso nasceu toda a confusão.

No primeiro clássico do ano, os amigos tiveram uma ideia que, talvez por consequência das cervejas que bebiam desde cedo, lhes pareceu naquela hora um verdadeiro achado: 
iriam ao estádio de namoradas trocadas. Com a jogada, o atleticano acompanharia a mulher do amigo na torcida do Galo, enquanto o cruzeirense iria com a namorada do outro em sua respectiva torcida.

De início as moças acharam a ideia fora de propósito afinal, quem havia dito que elas precisavam da companhia de homem para ir ao campo? Mas, terminada a partida, eram as duas só elogios à iniciativa. No fim das contas, as meninas acharam mesmo interessante a coisa de ter junto de si alguém interessado em elogiar os méritos do mesmo time, para variar.

Veio o segundo clássico e as mulheres se afeiçoaram de vez às novas companhias - há muito não conviviam com homens tão cheios de cuidados, tão dados às palavras comedidas, ao esforço da educação e da polidez. Para os rapazes, porém, a ideia genial de meses atrás se revelava um embaraço: sentiamse constrangidos pela intimidade que iam inevitavelmente estabelecendo com a namorada do outro - isso sem contar a chatice de evitar os palavrões mais obscenos, um martírio.

Desavisadas da angústia dos rapazes, as moças chegaram ao meio da temporada com uma decisão tomada: levari- am o namorado da outra não apenas aos clássicos, mas também às demais partidas de seus times. A essa altura, as meninas já estavam menos interessadas nos jogos que na possibilidade de empreender um flerte inocente com suas novas companhias, coisa que lhes fazia lembrar dos tempos de solteirice e seus deliciosos humores.

Chegou o terceiro clássico do ano e os rapazes já não sabiam mais o que fazer com os abraços de comemoração e de lamento que recebiam da namorada do amigo, cada qual em seu lado do estádio, os corpos se tocando em cada lance, em cada suspiro... As moças, ao contrário, não tardaram a descobrir, no fundo de seus copos, a óbvia solução para a coisa toda.

Ali pela quinta garrafa da resenha pós-jogo, uma olhou para a outra e, na graça de um piscar de olhos, decidiram que, para facilitar, trocariam logo os namorados, de vez - e brindaram a isso com a seriedade bêbada que só acomete os verdadeiros torcedores. Brinde feito, deram o assunto por resolvido, cada qual deixando para a outra a responsabilidade de desfazer a brincadeira. Nenhuma das duas se deu ao trabalho. 
Abismados, os rapazes só se deram conta da enrascada em que haviam se metido quando nada mais podiam fazer. De início, até ensaiaram uma reação, mas, sob o risco de terminarem os dois sem namorada alguma, acabaram concordando, resignados - ainda sem poder acreditar.

Naquele dia, cada homem foi embora de mãos dadas com a mulher do outro, em estado de suspensão. Pelo que sei, até hoje a troca não foi desfeita - ainda que, pelo que se tem falado, os dois agora estejam ameaçando mudar de time. 